\title{
Play and Learning: Inseparable Dimensions to Early Childhood Education
}

\author{
Shoaga, Opeyemi Ph.D \\ Department of Educational Foundations and Counselling, Faculty of Education, \\ Olabisi Onabanjo University, Ago-Iwoye, Ogun State, Nigeria \\ shoagaopeyemi@gmail.com
}

\section{Doi:10.5901/jesr.2015.v5n2p185}

\begin{abstract}
This article is a theoretical discourse which examined the role of play as an indispensable entity for learning in early childhood education. Despite the fact that play has been universally acclaimed to be instrumental in facilitating learning, improving social skills, developing intellectual and physical prowess at the early childhood stage, many limitations have been observed to hinder the total implementation of the use of play at this level of education. Both the home and the school factors have been identified to hinder the full implementation of the use of play in teaching children. In view of this, this paper employed a descriptive philosophical research method. The concept of play was extensively discussed as it relates to learning in early childhood education. Also, factors hindering the implementation of the use of play were raised. As a result of this, a re-orientation on the need and use of play in teaching children at certain levels of development (which include teaching of values and morals) was suggested. Also stressed is the need to de-emphasize writing (hands on paper). Teachers, heads of schools and parents need to be further enlightened on this. In addition, there is need for continuous on-the-job training for teachers in order to handle the challenges encountered while using play to teach children.
\end{abstract}

Keywords: Play, Learning, Education, Early Childhood Education

\section{Introduction}

The early years of a child's life are most significant from the standpoint of physical, social, cognitive and emotional development. Childhood is intrinsically valuable and this makes its own demands on the educational system. The interest in child education dates back to philosophers like Plato and child educators like Froebel, Dewey, Montessori among others. Childhood signifies a period of remarkable growth and development, therefore to despise the powers and needs of childhood could be socially out of place. It is a period of utmost importance both to children and adults.

United Nations Educational Scientific and Cultural Organisation (UNESCO 2004) state that the child's future personality is determined to a large extent by the learning capacity and value orientation of his first five years. By implication, the early years of the child are very significant for later development and needs. These early years are the formative period of a child's life when development is most rapid (Osanyin 2002). Long (1995) also buttressed this by affirming that the earliest years of a child's life keys to predicting ultimate success in school and life. As the child grows, the parents, the children and everything around him influence his world and help him in forming attitudes, behaviours and values. Hence, the growing appreciation for the education of the whole child where every stage of development is catered for as against the development of skills and knowledge is quite commendable (Grotwell \& Burton 2008).

The Education of the child helps to create meaning to his environment and world. The Nigerian National Policy on Education (NPE 2004) clearly identified the education of the child as the one that should inculcate in the child the spirit of enquiry and creativity through the exploration of nature, that is playing with toys in order to develop a sense of cooperation and team-spirit, and also to teach the rudiments of numbers, letters, colours, shapes, forms through play. By implication, the Nigerian government is particular about functional education of the child, that is, how play method can be used in achieving all round development in the child, having realized that play is one of the essential needs and interests of the child, (for proper growth and development).

On the contrary, many parents are usually in a hurry to introduce their children to academic learning. Little wonder, Durojaiye (1986) affirms that parents are eager to see their children get down to serious academic work even on their first day at school. He states that many (Nigerian) parents and teachers expect young children on first entering school to 'get down to the serious business of learning' and to learn to 'sit still and listen'. They regard nursery school as a simple extension of primary school enabling formal instruction to start a little earlier and therefore ensuring entry into primary school and a head-start on admission there. This attitude towards nursery education is wrong and harmful. It fails to 
recognize the ways in which young children can best learn and the things that they should best learn.

There is a general misconception about play. Many people see it as a trivial activity of the child which he engages in for recreation. According to Oduolowu (2001), teachers in Nigerian nursery schools are yet to fully understand early childhood education concepts and principles such as creative childhood education, and children's play. Teachers of nursery and primary schools have also demonstrated lack of understanding in the use of play in teaching pupils. In a study carried out by Ogunyemi (2004), it was discovered that teachers are moderately knowledgeable about the use of play and this gives some cause for concern.

\subsection{Statement of the problem}

The emphasis on the ideal way of teaching young children has been the concern of child educators, stakeholders and the society at large in Nigeria. Philosophers and child educators like Plato, Froebel, Dewey, Montessori and Maduewesi have postulated that learning should be promoted through the active involvement of pupils in activities of play. Despite all that has been said about play ranging from the views of child philosophers and psychologists to the importance of play especially as it affects the teaching and the learning of the child, it has been observed that play has not yet been given its rightful place in the teaching and learning of the pre-school child.

In support of this, researches that have been carried out on the relevance of play for developmental and cognitive enrichment, play has been reduced and even in some cases, completely wiped out from some early childhood classrooms in most countries (Fromberg 2006, Miller and Almon 2009). This is quite disheartening and poses a threat to the fundamental skills that pre-school pupils need to acquire.

\section{Literature Review}

Theoretically, two views on the nature of man are relevant here amongst others are homo faber (Man as a worker) and homo ludens (man as a player). The nature of man comprises these two features. Man is simply referred to as a worker, a maker, a fabricator of whatever happens to him. He is the controller of his environment and he makes out of it what he desires through his abilities and tools (senses). Thus, the child device means to transform his environment. In the process of trying to satisfy himself, he keeps altering his world again and again. On the other hand, homo ludens sees man by nature a playing being. This simply explains why children do not have to wait to be taught how to play. These two aspects of human nature are interwoven because in most situations, the need of man, social, physical and emotional, are satisfied through play.

Philosophers like Plato and Socrates are of the opinions that there are links between education and play. It is assumed that every child is naturally endowed with a sense of curiosity and will by every means, want to satisfy this inquisitiveness. Through play the child becomes an explorer of his environment and begins to discover solutions to the problems of life. In the discussion between Socrates and Glaucon, Socrates declared that because a free man (eleutheron) ought not to learn any study slavishly. Forced labours performed by the body don't make the body any worse, but no forced (biabion) study abides in the soul...Therefore, you best of men, I said, don't use force (bia) in training the children (paidas) in the subjects, but rather play (paidzontas). In that way you can better discern what each is naturally directed toward...' (The Republic online edition 7.536e)

Socrates made the point that children learn better through play. He believed that the learning gained through play would stay with the child while the forced learning would be forgotten. Play to him, is more than just the activity of the child but is part of the nature of the child. Hence, the predominant activity that is generally recommended in early childhood is activity-oriented. Whatever the child is exposed to through activities and interaction constitutes an experience which is likely to be permanently internalized. This is buttressed by a Chinese saying that: "What I hear, I forget, what I see, I remember, what I do, I know". By implication what the child is actively involved forms an experience which produces knowledge in him. Interaction with the environment is best demonstrated through the activities of play.

\subsection{George Herbert Mead's Theory of Play as Symbolic Interactionism}

George Herbert Mead (1863-1931), who is an American philosopher and social theorist worked extensively on the mind, self, and society at a period when emphasis was laid on cruelty and self-centeredness as against cooperativeness and sympathy among children. In view of this, Mead's idea was associated with the theoretical perspective of symbolic interactionism. This theory can be regarded as a theory of socialization through which the individual self is given 
expression. The central concept of this theory is that people who interact mutually tend to influence one another. Social interaction takes place through shared symbols such as words, definitions, roles and so on. This implies that the concept of self emerges as a result of experience. It was not in the child when he was going to take part in the activity. It surfaced from the acquired experiences. In view of this, children continue to adapt and change their behaviour as a reaction to how others react to them.

According to Freud, the mind of the child comprises of three separate systems which include the id, ego and the superego. The id and ego have attributes that one can associate with children's awareness of self in early life. The id comes into operation only to satisfy pleasure which focuses on immediate personal satisfaction. For instance, the child reacts to actions such as hunger by crying and this reaction is seen as a stimulus for the other person's reaction, for example, breastfeeding by the mother. Consequently the child becomes aware that his actions can stimulate responses from others.

The second component which is the ego is learned as the child begins to interact with his environment and the people in it. At this stage, the ego is differentiated from the id, hence he tries to satisfy the id but gives consideration to the circumstances around. For example, a child at the id stage who is hungry cries, salivates or even grabs any food within his reach not minding who the food is actually meant for. All that he is interested in is satisfying his immediate need. On the contrary, by the time the child gets to the ego stage he learns to wait to be given food, rather than take whatever he sees. At this stage, the child begins to realise that activities have meaning and thus becomes conscious of the self which has emanated from his interaction with his environment. Although all these stages of child development are innate, it comes to the fore as a result of interaction and as a way of solving problems that arise in the process of dealing with the environment.

According to Mead, the concept of self develops through three forms of activities which include language, play and games. The child's symbolic abilities are manifested in language development. Language is communication through significant symbols. This enables a child to accommodate the attitudes of others towards self. Language creates the foundation for an awareness of self in the child. Whenever the child interacts with another child or assumes a role, he is able to store such an activity in his memory and from that point, he is able to look back at self and even interact with self as an entity. In situations like this, the child is able to maintain a dialogue with 'self' as a way of re-enacting a previous experience. All these help to serve as a means of reflecting upon self.

Hence, play helps the child to understand himself as well as the people around him. The concept of self is formed as a result of social experience and activity. Mead viewed it as the outcome of a process of social experience and activity which implies that its development in any individual is as a result of interactions with other individuals through play, games or sports (Scheffler 1986). For example, when a child plays cards alone, he tries to play both for and against himself. He is able to play these two different roles as a result of previous interactions with others when playing cards.

A child who engages in play or games interacts with other children and in the process appreciates the uniqueness of the other person. As stated earlier, a child who engages in play is conscious of the real life situation especially when he assumes a social role such as a professional (doctor or teacher), a parent and so on during play. When a child is engaged this way, he is able to know why people behave the way they do. This aspect of play may be compared to Piaget's description of play as assimilation. In this case, the child assimilates the roles he has observed in people, especially adults, around him by acting them out in play. This is in no way similar to his natural character. The role taken is that specific role which the child is playing at a particular point in time.

The behaviour which the child exhibits as a result of his participation in play is what Mead refers to as the "specific other" (Mead 1934). The specific other stands for the role which the child assumes when he is engaged in play. This is the experience which the child has acquired in the process of play. When playing, a child engages in a single role at a time but when it comes to games, it involves a much more complex skill because the individual involved needs to internalise not only the character of a single and specific other but he has to master and comprehend the rules of the game as well as the roles of others who are involved in the game. The attitudes of all others result in the 'generalised other'. It is from this generalised other that the individual defines his own conduct. When the individual is able to view himself from the standpoint of others, a concept of self has been formed.

The idea of self at this stage is not only at the level of individual reactions to things. It also includes the views of others who are involved in such an activity because the self in the child is a product of social interaction with his peers. The child by nature is egocentric, that is, he loves doing things his own way. With play and games, the child is able to maintain close relationship with his peers and is also able to see things from own perspective especially when acting or participating in role-play. When engaged in such, the child is able to understand why people behave the way they do, develop respect for rules, gain self-discipline and appreciate other people's cultures and beliefs. 
This theory places value on the role of play as a way of achieving optimal life experiences. While children are at play, they are exposed to all forms of activities that they wish to engage in and even act any role they wish to act which they may not be able to exhibit in real life. For example, a child may cook rice in a tin of milk as role-playing but the mother would not allow him to come near the gas stove for safety reasons. The quality of the experience is highly valued.

Uninterestingly, teachers use this school work to replace play and hands-on learning in the early years of their children. Most Nigerian parents send their children 'to play' when they want to get busy with "serious work" and often see the time they spend with children as play time! This indicates the extent of parental misconceptions of play in school. Dako-Gyeke (2013) reported that parents disliked the use of play by teachers as instrumental tool in pre-primary classrooms. Parents are eager to have their children engaged in real academic work hence they agitate for early childhood programmes that are academic focused. Albeit, parents who appreciate play are concerned with designing special environments for play activities hence children are deprived of the fun and creativity which come with play.

\subsection{The Concept of Play}

Play is regarded as the major characteristic mode of behaviour of the child. There is no universally acclaimed definition to the concept of play and as a result, it means several things to different people depending on the angle from which it is viewed. The psychologists, philosophers and educators such as Froebel and Rousseau see play as the highest expression of human development in childhood. Froebel, as cited in Torkilden (1992) stated that play is the purest, most spiritual activity of man at this stage...a child that plays thoroughly with self-active determination, perseveringly until physical fatigue forbids, will surely be a thorough, determined man, capable of self-sacrifice for the promotion of the welfare of himself and others. In his view, play of the child is an all-encompassing activity which not only promotes the total wellbeing of the child but also allows for integration and interpersonal relationship with significant others around him.

Play gives the child room to express self without bias or prejudice. It promotes sincerity and tolerance.

Ireland National Play Policy (2004) captures play to be a freely chosen personally directed behaviour, motivated from within by needs, wants and desires. Play can be fun or serious. Through play children explore social, material and imaginary worlds and their relationship with them, elaborating all the while a flexible range of responses to the challenges they encounter. By playing children learn and develop as individuals and as members of the community.

This affirms that play is freely entered into by the child without compulsion or force. When children are at play, they are in control, they take charge of their environment and situations around them to suite their pressing needs. They also manipulate their immediate environment to unleash their creative potentialities. Play is an activity of the child which he willingly and spontaneously goes into. It transcends human culture and race. The play of the child is enculturative. It helps the child to learn the norms and values of the society. It also promotes his social wellbeing (Hyun 1998). Play of the child enhances the cognitive, social, physical and emotional development of the child, (Ginsburg 2007, UNESCO 2007) involvement of children in play improves their competencies of several skills and also allows them to overcome several challenges. It is a free choice activity which is rewarding in itself. It is self-motivated and gives the pupils ample opportunities to create and re-create meanings out of their environment. The play of the child is open-ended.

In view of the fact that there are no definitive meanings ascribed to play, several attempts have been made to define play with respect to its characteristic, which are;

- Play is voluntary in nature: children engage in play willingly and they change the direction of play to please themselves.

- Play is meaningful to the players: when children play, it usually reflects what they already know and it creates a platform upon which further knowledge can be built.

- Play is low risk: when children are at play they are exposed to minimal risks of failing. Despite the fact that their play can be challenged, every mistake creates opportunities to explore and surmount new challenges.

- Play is spontaneous and open to the surrounding world: through play children's curiosity is satisfied. It enhances creativity and creates an avenue to discover the inherent benefits in their play activities

- Play is symbolic: while children are at play, they tend to make sense out of their world based on their level of interaction with the environment. They transform reality into symbolic representation of their world.

- Play is active: play of the child is usually physically exhaustive. It engages all the sense organs of the child particularly his physical and mental capabilities.

- Play is sociable: when children play it entails active interaction with friends and peers. It promotes team spirit and cooperation.

- Play incorporates deep involvement and sustained concentration: when children are at play they are capable 
of getting deeply involved in their activity and still concentrate even when their peers are also partaking of the play. Children can engage in and sustain solitary play in the midst of group activities.

- Play brings joy, sense of humour and excitement: children engage in play because it is intrinsically rewarding. They engage in it for the joy they obtain from actively participating in it.

\subsection{Play and learning}

The activities of child's play has been closely linked with the education and learning of the child. Several researchers have observed and identified that play is a major and central ingredient for the holistic development of the child. Isenberg and Quisenberry (2011) stated that preschoolers develop and refine motor skills, experience the joy of mastery and develop the use of basic academic skills such as counting, reading and writing through play. Seo and Ginsburg (2003) identified that, children between the ages 4 and 5 build foundational mathematical concepts during free play. It was further noted that the social class of the pupils had nothing to do with this but three categories of mathematical activities (pattern and shape play, magnitude play and enumeration play) were prevalently used by the pupils.

Furthermore, in a review of 12 studies on literacy and play, Roskos and Christie (2004) submitted that play provides settings that promote literacy activity, skills and strategies and can in the same vein provide opportunities to teach and learn literacy. Pellegrini (2005) also submitted that elementary age children who engage in free play during recess returned to the class more attentive to their work. He further noted that children who usually go for recess performed better in reading and mathematics than children who do not. The play of the child has two major roles to perform and they are; promoting imaginary situation that permits children to come to grips with unrealisable desires and promotes self-regulation also, play contains rules for behaviour (Berk and Winsler 1995).

Hutt (1979) cited in Kernan (2007) categorised play into three groups which are epistemic, lucid and games with rules. According to him, when the engage in epistemic play, he explores objects and materials and by so doing, he gathers knowledge about his world through his senses. This is closely related to Piaget's sensory play. While engaging in lucid play, the child's play is more advanced to imaginative, fantasy and socio-dramatic play. At this stage, he is able to play even when the real object of play is not available. He is able to substitute specific play objects with imaginary ones. Games with rules are the complex play/games of the child where he designs his own play and forms his own rules. The child at this stage deals with external rules and is able to internalise things even when they are not concrete. The play of the child is very technical at this level because he deals with symbols.

\section{Discussion and Findings}

The theory of symbolic interactionism has highlighted some important aspects of play as a means of fostering cooperation among children. This allows them the opportunity to influence themselves positively. It also gives room for the child to be able to maintain a balance between 'self', 'the specific other' and the 'generalised other'. While playing the role of another, the child is able to differentiate between himself and the character of the person he is assuming. Such play keeps the child cognitively alert, trying to figure out what his playmates are likely to do and thinking of possible responses to such anticipated actions.

It also enables the child to make sense out of his world based on his level of interaction with his environment. This suggests that the environment of the child should appeal to his sense of curiosity and it should also be able to challenge his intellect. This theory enables the child to acquire experience through exploring the environment and interaction with peers. It equally facilitates the unfolding of the child's potential. The child, by nature, is a social being who cannot exist or live in isolation. It further corroborates Freud's personality theory where the child is basically concerned about satisfying the physiological needs of food and other sexual instincts by eliciting response from the other party by his own behaviour. Furthermore, the child uses language to express himself and this allows the 'self' to engage in conversation with the 'generalized other'. The development of 'self' also depends on thinking.

Mead's theory is philosophically significant because of its emphasis on social interaction. Social interaction is central to ethics, the philosophical study of 'good' and 'bad' human behaviour in a social context. One can infer that because social interaction is the setting that enables the child to watch other human beings in action, it is also the forum where the child learns to be human in many ways-comportment, language use and interpretation of cosmic phenomena around them. These avenues of human behaviour also constitute avenues of social relationship which can in turn be interpreted as 'good', 'bad', 'moral' or immoral. The child first learns to interprete like others and as he matures, learns to behave and anticipate others' behaviour in socially acceptable ways. 
While the child may learn from others' behaviour in the Piagetian modes of concrete operational experiences, play is an important avenue to show that the child has learnt and has internalised what has been learnt from observing older people around. Through play, the child can demonstrate what he has learnt in the cognitive, affective and psychomotor domains. Affective learning is the foundation for moral behaviour, personality and social development. What has been learnt at the cognitive and psychomotor domains can also be affectively demonstrated to show the child's level of moral behaviour such as being kind, selfish, humble and respectful. These theories do not end with being aware of self through play alone but it also allows the child to appreciate and value others.

The intrinsic worth of an experience which the child acquires from play is permanent. Children learn much while at play and learning ranges from cognition, values to morals. All these come together to form the personality of the 'self' of the child. A child who through play knows that whoever takes somebody else's property without permission has stolen makes sure that he does not take mummy's biro from her bag without first asking her. Many of the experiences that children acquire are learnt through play and by trial and error. As a result of this, children are allowed to play and acquire experiences. It is the amount of experiences that the child acquires that dictates his level of socialization. Play aids the child's social and personal development as well as the socialization process. Barnett (1990) is of the opinion that play is a major context for learning social skills, social communication and facilitating social integration. In the contemporary African setting, play is seen as a medium of learning the social norms and values. The play activities that are usually engaged in include running, jumping, wrestling, dancing, folklores, rendering satirical chants and moonlight plays.

Folklore is a major avenue of teaching morals and social values. As stories are told to the child, reasons are given for conforming to the values of one's society in order to be acceptable and or relevant. Games such as Ayo, Suwe, etc. among the Yoruba ethnic group in south-west, Nigeria do not only teach the child co-operation but the rudiments of counting and numerals.

Through play, children transform what they see in life into play and transform what they experience in play into life situations. Play helps the child to translate and express his experience. Hence play activity becomes reciprocal with real life situations. As a result of this responsiveness to situations and people through play, provides a basis for subconscious acquisition of understanding of self and others.

Although the child develops socially from birth to early childhood, involvement in free play creates avenues to engage in conflict resolution because children also disagree when they engage in play. Team-spirit is encouraged and children are taught to co-operate with one another especially when playing a game in which the opponent is to be defeated. Language is also developed. Children from various ethnic backgrounds come together to play and in the process, they pick one or two expressions from themselves.

\section{Deduction and Recommendations}

The underutilization of play in teaching children and the level of ignorance displayed by stakeholders of education which include the parents, the teachers and the significant adults is a source of worry. Play of the child goes beyond the outdoor activity of the child or the hide and seek and other indoor games. Play has been discovered to have inherent potentialities that enhance literacy in child education. Its inclusion in early childhood education promotes a balanced curriculum. The play of the child in school cannot stand alone. It cannot be taught in isolation hence it has to take an integrative approach in order to make meaning and achieve what it is out to achieve in the school setting. The use of play has to take some specific and organized approach for it to make sense in the learning situation. Drawing from literature, play has been found to be synonymous with a happy and healthy childhood.

Adopting play method in schools enhances learning; therefore both play and learning stimulate one another and cannot be treated in isolation. Although, play may not really be a unique contributor to learning, it has been discovered to be a sufficient condition for learning which brings together the most social, academic and emotional tools that humans bring to bear on the problems they encounter. (Seligman, Railton, Baumeister \& Sripada 2012).

When play method is engaged, it allows the child to consciously gain control of his environment in a lifelong process. However, adopting play in schools should be structured in a way that will create distinctive difference from free and structured play. The teacher should ensure that the play of the child is guided and driven towards achieving stipulated goals. Childhood educators are challenged with providing stimulating environment for the child to play and also need to support children's learning by becoming co-players, guiding and serving as role-models. In view of this, the school should make available tools to assess quality play, improve the quality and scope of play in early learning environment, and make available time, space and good conditions for play while developing both indoor and outdoor play facilities. 
Opportunities should be made available to teachers to engage in training and retraining exercises in order to get them empowered for the challenges encountered while using play method in teaching children.

Parents on the other hand need to be well informed about the benefits of both structure and unstructured play and the need for the child to actively engage in it for holistic development.

Metaphysically, children are playing beings that play from natural instinct, hence schools should be built with adequate and relevant play facilities and structures put in place. It should be noted that various nations of the world are canvassing that 'no child should be left behind' and for this to be implemented the nature and nurture of the child should be paramount in any educational policy.

The Government of Nigeria on her part should give approvals of schools structures with emphasis on wellfurnished play grounds and recreational facilities for children that are both out door and in door.

\section{Acknowledgment}

I wish to extend my appreciation to Professor Oluremi-Ayodele Bamisaiye of the University of Ibadan, Nigeria, for supervising the doctoral research from which this article was drawn.

\section{References}

Barnett, L.A (1990). Developmental benefits of play for children. Journal of leisure Research. 22(2) 138-153.

Berk, L. and Winsler, A. (1995), Scaffolding children's learning: Vygotsky and early childhood education, Vol. 7 of NAEYC Research into Practice Series Washington D.C., National Association for the Education of Young Children.

Blumer \& Mead, (1980). Social Behaviourism and symbolic Interactionism. American Sociological Review. Vol. 45. 409-418

Dako-Gyeke, M. (2013). Using play as a Curricular Tool in Pre-Primary Classrooms: Challenges Encountered by Teachers in Ghana. Journal of Educational and Social Research. 3(1) 247-249.

Durojaiye, S.M., (1986). Practical Methods for Nursery schools. Ibadan. University Press Limited.

Eysenck, M.W. (1998). Psychology an Integrated Approach. Harlow, England. Pearson Education limited.

Federal Government of Nigeria (2004). National Policy on Education. $4^{\text {th }}$ Edition.

Fine, G.A. (1986) interpreting the sociological classics: Can there be a "true" meaning to Mead? Symbolic interaction 19. p. 129-146.

Fromberg, D. P. (2006). Kindergarten education and early childhood teacher education in the United States: Status at the start of the 21st century. Journal of Early Childhood Teacher Education. 27, 65-85.

Ginsburg, K. R. (2007). The importance of play in promoting healthy child development and maintaining strong parent-child bonds. Pediatrics 119(1), 182-190.

Grotwell, P.G. \& Burton, Y.R. (2008). Early Childhood Education: Issues and Development. New York Nova Science Publishers.

Hutt, C. (1979). Play in the Under-Fives: Form, development and function. In J. Howells (ed.) Modern Perspectives in the Psychiatry of Infancy. New York: Brunner/Mazel

Hyun, E. (1998). Making Sense of Developmentally and Culturally Appropriate Practice (DCAP) in Early Childhood Education. New York: Peter Lang Publishing.

Isenberg,J \& Quisenberry, N. (2011) Play: Essential for all Children. A Position Paper. Olney, M.D: Association for Childhood Education International.

Kaprov Y.V. (2005). Three - to six year olds: Socio dramatic play as the leading activity during the period of early childhood. In Y.V. Kaprov, The Neo- Vygotskian Approach to child development. Cambridge University Press.

Kernan, M. (2007). Play as a context for early learning and development. The early childhood curriculum framework. National council for curriculum and assessment. Retrieved on 23-02-2014from: http://www.ncca.ie/en/Curriculum_and_Assessment/Early_ Childhood_and_Primary_Education/Early_Childhood_Education/

Krentz, A.A Play and Education in Plato's Republic, http://www.bu.edu/wcp/papers/Edu/Edukren.htm

Mead (1934) (ed) Play, the game and the generalized other in Morris Mind self and society University of Chicago.

Miller E, \& Almon J. (2009) Crisis in the kindergarten: Why children need to play in school. College Park, MD: Alliance for Childhood.

National Playing Fields Association, PLAYLINK and the Children's Play Council (2000, p.6 cited in Ready Steady Play! A National Play Policy, National Children's Office, 2004.

Oduolowu, E. A., (2001) Teachers perception of creativity and the Nigerian creative child. journal of educational studies. Ibadan. Vol. 1(1) p.79-80.

Ogunyemi, F.T., (2004) Play facilities in selected Nursery and Primary Schools: Implications for Assuring Quality in Early Childhood Education. Assuring Quality in school Practices and Strategies. Ist National Conference of the Institute of Education.

Osanyin F.A (2002) Early Childhood Education in Nigeria. Lagos. Concept Publication.

Pellegrini, AD (2005) Recess: Its Role in Development in Education. Mahwah, NJ: Lawrence Erlbaum Associates

Roskos, K. \& Christie, J. (2004). Examining the play-literacy interface: A critical review and future directions. In Zigler EF, Singer DG, Bishop-Josef SJ, eds. Children's playhood Literacy. 1(1) 59-89

Scheffler, I. (1986): Four Pragmatists. A Critical Introduction to Peirce, James, Mead \& Dewey. London. Routledge \& Kegan Paul. 
Seligman, M., Railton, P., Baumeister, R., \& Sripada, C. ( 2012) Drawn into the future or driven by the past.

Seo, K.H, \& Ginsburg, H.P (2003). What is developmentally appropriate in early childhood mathematics education? Lessons from new research. In: Clements DH, Sarama J, DiBiase AM, eds. Engaging Young Children in Mathematics: Standards for Early Childhood Mathematics Education. Mahwah, NJ: Lawrence Erlbaum Associates.

Torkilden, G. (1992). Leisure and Recreation Management. London. E and F.N Spon p.48-49

UNESCO. (2004) Early Education and Development. ortal.unesco.org/en/ev.phb2004.

UNESCO. (2007). Country profile commissioned for the education for all global monitoring report: Strong foundations, early childhood education care and education. Geneva, Switzerland 